\title{
Bicyclic [1,3,4]Thiadiazolo[3,2- $\alpha]$ Pyrimidine Analogues: Novel One-Pot Three-Component Synthesis, Antimicrobial, and Antioxidant Evaluation
}

\author{
Umesha K. Bhadraiah ${ }^{(\mathbb{D})}$, Vrushabendra Basavanna ${ }^{2 \mathbb{D}}$, Doddahosuru M. Gurudatt ${ }^{3 \mathbb{D}}$, Rajendra \\ Prasad Shivalingappa 4 (D), Nagarakere S. Lingegowda 2 (D), Srikantamurthy Ningaiah 2,* (D) \\ 1 Department of Chemistry, Yuvaraja's College, University of Mysore, Mysuru-570 005, Karnataka, India \\ 2 Department of Chemistry, Vidyavardhaka College of Engineering, Visvesvaraya Technological University, Mysore-570 \\ 002, Karnataka, India \\ 3 Department of Studies in Organic Chemistry, University of Mysore, Mysuru-570 006, Karnataka, India \\ 4 PG Department of Chemistry, Davangere University, Shivagangothri, Davangere-577007, Karnataka, India \\ * Correspondence: srijmn@vvce.ac.in;
}

Scopus Author ID 55786395000

Received: 28.12.2020; Revised: 19.01.2021; Accepted: 23.01.2021; Published: 31.01.2021

\begin{abstract}
A novel one-pot three-component synthesis of 1-(7-methyl-2,5-diphenyl-5H$[1,3,4]$ thiadiazolo(3,2- $\alpha$ )pyrimidine-6-yl)ethanone (4a-i) derivatives via cyclo-condensation of substituted 2-amino-[1,3,4]thiadiazole (1a-c), acetylacetone (2) and various aromatic aldehydes (3a-c) in the presence of $p$-toluene sulfonic acid (PTSA) in acetonitrile. Spectral data and elemental analysis have characterized the newly synthesized compounds. The new analogs were screened for their antibacterial and antifungal activities. The majority of the tested compounds displayed significant to moderate efficacy against most of the designated organisms. Among the tested compounds, 4b, 4e, and $4 \mathrm{~h}$ showed noteworthy efficacy against selected microbes, and compounds $4 \mathrm{c}$ and $4 \mathrm{i}$ were found to be exceptionally efficient against selected fungal strains. Compound 4c, 4e, 4f, 4i were also designated as best antioxidants against NOx.
\end{abstract}

Keywords: one-pot three-component synthesis; 1,3,4-thiadiazolo[3,2- $\alpha]$ pyrimidine; antibacterial activity.

(C) 2021 by the authors. This article is an open-access article distributed under the terms and conditions of the Creative Commons Attribution (CC BY) license (https://creativecommons.org/licenses/by/4.0/).

\section{Introduction}

Multi-component reactions [1] are one-pot processes in which three or more reactants come together in a single reaction vessel to give a final product. The simplest and most straightforward procedure involves three-component one-pot cyclo-condensation [2] of the acetoacetic ester, aldehyde, and third component as urea/thiourea [3] in strong acidic condition to give biologically active Biginelli compounds [4] like pyrimidinones or 3,4dihydropyrimidine-2(1H)-ones. Zhao and co-workers [5] synthesized the novel ethyl 7-methyl 2,5-diphenyl-5H-[1,3,4]thiadiazolo[3,2- $\alpha]$ pyrimidine-6-carboxylate derivatives through onepot three-component chemical transformation by microwave irradiation using acetic acid without any catalyst. Synthesis of 1,3,4-thidiazolo-(3,2- $\alpha$ )pyrimidine-6-carbonitrile derivatives was achieved [6] using optimized reaction conditions. It showed good binding mode in the active site of STAT3 enzyme inhibitors [7] to treat breast cancer [8]. The cytotoxic activity [9] was found in 2-alkanesulfinyl/alkanesulfonyl-7-methyl-5H-1,3,4-thiadiazolo[3,2- $\alpha$ ]pyrimidin- 
5-one derivatives [10], especially the strong activity was shown by the compounds which have electrophilic substituent group on the 2-position such as alkyl sulfoxide or alkyl sulfone.

New series of biologically active sulfonamide derivatives [11] of $[1,3,4]$ thiadiazolo[3,2- $\alpha]$ pyrimidine were synthesized and investigated for their antitumor activity. Some of them were tested for their in vitro and in vivo antitumor activities. Abdel Rahman and co-workers [12] synthesized the substituted imidazo[2,1- $\beta$ ]-1,3,4-thiadiazoles, substituted 1,3,4-thiadiazolo[3,2- $\alpha$ ]pyrimidines and 1,3-disubstituted thiourea. Most of the compounds exhibited potent cytotoxic activity against tumor cell line A549 (non-small cell lung cancer cell line) [13] using sulforhodamine B (SRB) standard method [14]. Recently, Nagaraju and co-workers reported green synthesis [15] and characterization of novel $[1,3,4]$ thiadiazolo/benzo[4,5]thiazolo[3,2-a]pyrimidines via the multi-component reaction between chosen substrates of 1,3,4-thiadiazole-amines or 2-amino-benzothiazole, aldehydes and active methylene compounds in ethanol solvent at room temperature using vanadium oxide loaded on fluorapatite as a robust and sustainable catalyst. Recently, 7-oxo-7H$[1,3,4]$ thiadiazolo[3,2-a]pyrimidine-5-carboxylate derivatives were conveniently synthesized under mild condition through regioselective cycloaddition reactions [16].

The thiadiazolo-pyrimidine nucleus and its substituted products, as well as several other substances, belongs to the pseudo purine class, were reported to have interesting biological profiles, including the antiviral [17-18], anti-cancer [19], antibiofilm [20], antitumor [21], antitubercular and antibacterial [22] activities. In last few decades, these analogues were synthesized as PARP1 Inhibitors [23], STAT3 Inhibitor [24], anticancer [25], antiglycation [26] and antioxidant [27]. This observation draws our attention to develop the synthesis of some bicycle heterocyclic compounds containing 1,3,4-thiadiazine fused with pyrimidine moiety, i.e., 1-(7-methyl-2,5-diphenyl-5H-[1,3,4]thiadiazolo(3,2- $\alpha$ )pyrimidine-6-yl)ethanone (4a-i) derivatives and their antimicrobial and antioxidant studies.

\section{Materials and Methods}

All chemicals/reagents were purchased from Merck Chemicals (India) and Fluka chemicals (India). The melting points were measured with micro melting point apparatus and are uncorrected. IR spectra were recorded in $\mathrm{KBr}$ pellets on Shimadzu 8300 spectrometer. The ${ }^{1} \mathrm{H} \mathrm{NMR}\left(\mathrm{CDCl}_{3}\right)$ was recorded on an Agilent-NMR-vnrms $400 \mathrm{MHz}$ spectrometer and ${ }^{13} \mathrm{C}$ NMR (DMSO-d6) spectra were obtained on a Varian Gemini $400 \mathrm{MHz}$ spectrometer. The chemical shifts are expressed in ppm (TMS was used as an internal standard). Mass spectra were obtained on Agilent 6330 ion trap spectrophotometer, and elemental analysis was performed on a Jusco micro-analytical data unit. TLC was performed on pre-coated silica gel sheets (HF 254, TLC was performed on pre-coated Silica Gel sheets (HF 254, Sd-fine), and visualization of the spots was done in iodine vapor and/or UV light. Chromatographic separation was carried out on silica gel (60-120) mesh using petroleum ether: acetone $(9: 1)$ as eluent.

\subsection{General procedure for the synthesis of 2-amino-5-phenyl-1,3,4-thiadiazole (1a).}

A mixture of benzaldehyde $(1.06 \mathrm{~g}, 10.00 \mathrm{mmol})$, thiosemicarbazide hydrochloride $(1.40 \mathrm{~g}, 15.00 \mathrm{mmol})$ in $20 \mathrm{ml}$ of ethanol was refluxed for about 30 minutes. After completing the reaction, the reaction mixture was cooled to room temperature, filtered, and dried to get solid white thiosemicarbazones. The obtained thiosemicarbazones were oxidized with $10 \%$ 
ferric chloride solution $(10 \mathrm{ml})$ in the presence of ethanol $(30 \mathrm{ml})$ for about 30 minutes to give yellow solid, which was filtered, extracted with chloroform (3 x $20 \mathrm{ml})$, washed with water, dried and recrystallized from ethanol to give cyclized pale yellow solid 2-amino-5-phenyl1,3,4-thiadiazole [28] 1a in 80\% yield (1a, 1.41g).

2.2. Typical procedure for the synthesis of 1-(7-methyl-2,5-diphenyl-5H[1,3,4]thiadiazolo[3,2- $\alpha]$ pyrimidine-6-yl)ethanone (4a).

A mixture of acetylacetone $(2.00 \mathrm{~g}, 20.00 \mathrm{mmol})$ and benzaldehyde $(3 \mathrm{a}, 1.06 \mathrm{~g}$, $10.00 \mathrm{mmol})$ in acetonitrile $(25 \mathrm{ml})$ was refluxed on a water bath in the presence of acidic PTSA $(2.50 \mathrm{~g}, 15.00 \mathrm{mmol})$ for about 30 minutes. Meanwhile, the 2-amino-5-phenyl-1,3,4-thiadiazole (1a, $1.77 \mathrm{~g}, 10.00 \mathrm{mmol})$ was added to the above reaction mixture and again refluxed for about 50-60 minutes. After the completion of the reaction, the reaction mixture was cooled to room temperature, extracted with chloroform $(3 \times 25 \mathrm{ml})$, washed with water $(2 \times 25 \mathrm{ml})$ and $2 \%$ dilute $\mathrm{HCl}$ solution, finally dried over anhydrous $\mathrm{Na}_{2} \mathrm{SO}_{4}$. The solvent was evaporated to give yellow viscous solid, which was subjected to column chromatographic technique (silica gel 60120 mesh) using ethyl acetate and petroleum ether (2:8) as eluent to get an pale yellow solid 1(7-methyl-2,5-diphenyl-5H-[1,3,4]thiadiazolo(3,2- $\alpha$ )pyrimidine-6-yl)ethanone $4 \mathrm{a}$ in $80 \%$ yield $(2.77 \mathrm{~g})$; m.p. $122-124^{\circ} \mathrm{C}$. IR $\left(\mathrm{KBr}, \mathrm{cm}^{-1}\right): \gamma 2972(\mathrm{C}-\mathrm{H}), 1728(>\mathrm{C}=\mathrm{O}), 1610(\mathrm{C}=\mathrm{N}) \mathrm{cm}^{-}$ 1; ${ }^{1} \mathrm{H}$ NMR $\left(\mathrm{CDCl}_{3}\right): \delta 2.27$ (s, 3H, $\left.-\mathrm{COCH}_{3}\right), 2.96\left(\mathrm{~s}, 3 \mathrm{H},-\mathrm{CH}_{3}\right), 4.60$ (s, 1H, -CH-), 7.23-7.80 (m, 10H, Ar-H); ${ }^{13} \mathrm{C}$ NMR (DMSO- $d 6$ ): $\delta 21.2$ (C-10), 27.4 (C-12), 64.6 (C-5), 126.5 (C-22), 127.0 (C-20 and C-24), 128.6 (C-21 and C-23), 129.0 (C-15 and C-17), 129.6 (C-14 and C18), 130.8 (C-13), 131.2 (C-16), 132.2 (C-6), 143.4 (C-19), 143.8 (C-2), 151.8 (C-7), 160.4 (C9), 196.6 (C-11); MS for $\mathrm{C}_{20} \mathrm{H}_{17} \mathrm{~N}_{3} \mathrm{OS}: 347.12\left(\mathrm{MH}^{+}, 100 \%\right), 348.12\left(\mathrm{MH}^{+1}, 24.6 \%\right), 349.14$ $\left(\mathrm{MH}^{+2}, 6.2 \%\right)$; Elemental analysis: Calculated: $\mathrm{C}, 69.12 ; \mathrm{H}, 4.95 ; \mathrm{N}, 12.10$; Found: $\mathrm{C}, 69.10$; $\mathrm{H}, 4.92 ; \mathrm{N}, 12.08$.

\subsection{1-(5-(4-methoxyphenyl)-7-methyl-2-phenyl-5H-[1,3,4]thiadiazolo[3,2- $\alpha]$ pyrimidine-6-} yl)ethanone $(4 b)$.

Obtained from 2-amino-5-phenyl-1,3,4-thiadiazole (1a, 1.77g, 10.00mmol), acetylacetone $(2.00 \mathrm{~g}, 20.00 \mathrm{mmol})$ 4-methoxybenzaldehyde $(3 \mathrm{~b}, 1.36 \mathrm{~g}, 10.00 \mathrm{mmol})$ and PTSA $(2.50 \mathrm{~g}, 15.00 \mathrm{mmol})$ as yellow solid, yield $85 \%(3.20)$, m.p. $138-140^{\circ} \mathrm{C}$. IR $\left(\mathrm{KBr}, \mathrm{cm}^{-1}\right): \gamma 2952$ $(\mathrm{C}-\mathrm{H}), 1730(>\mathrm{C}=\mathrm{O}), 1620(\mathrm{C}=\mathrm{N}) \mathrm{cm}^{-1} ;{ }^{1} \mathrm{H} \mathrm{NMR}\left(\mathrm{CDCl}_{3}\right): \delta 2.24\left(\mathrm{~s}, 3 \mathrm{H},-\mathrm{COCH}_{3}\right), 2.98(\mathrm{~s}$, $\left.3 \mathrm{H},-\mathrm{CH}_{3}\right), 4.62$ (s, $\left.1 \mathrm{H},-\mathrm{CH}-\right), 7.32-7.80$ (m, 9H, Ar-H); ${ }^{13} \mathrm{C}$ NMR (DMSO- $d 6$ ): $\delta 21.0(\mathrm{C}-10)$, 27.2 (C-12), $56.4\left(-\mathrm{OCH}_{3}\right), 64.2$ (C-5), 114.6 (C-21 and C-23), 126.2 (C-20 and C-24), 128.6 (C-15 and C-17), 129.4 (C-14 and C-18), 130.8 (C-13), 131.2 (C-16), 132.2 (C-6), 136.4 (C19), 144.2 (C-2), 151.4 (C-7), 160.6 (C-9), 196.8 (C-11); MS for $\mathrm{C}_{21} \mathrm{H}_{19} \mathrm{~N}_{3} \mathrm{O}_{2} \mathrm{~S}: 377.12\left(\mathrm{MH}^{+}\right.$, $100 \%), 378.12\left(\mathrm{MH}^{+1}, 24.6 \%\right), 379.14\left(\mathrm{MH}^{+2}, 5.8 \%\right)$; Elemental analysis: Calculated: $\mathrm{C}$, 66.80; H, 5.08; N, 11.14; Found: C, 66.78; H, 5.02; N, 11.12 .

2.4. 1-(5-(4-chlorophenyl)-7-methyl-2-phenyl-5H-[1,3,4]thiadiazolo[3,2- $\alpha]$ pyrimidine-6yl)ethanone (4c).

Obtained from 2-amino-5-phenyl-1,3,4-thiadiazole (1a, 1.77g, 10.00mmol), acetylacetone $(2.00 \mathrm{~g}, 20.00 \mathrm{mmol})$ 4-chlorobenzaldehyde $(3 \mathrm{c}, 1.40 \mathrm{~g}, 10.00 \mathrm{mmol})$ and PTSA $(2.50 \mathrm{~g}, 15.00 \mathrm{mmol})$ as yellow solid, yield $82 \%(3.14 \mathrm{~g})$, m.p. $152-154^{\circ} \mathrm{C}$. IR $\left(\mathrm{KBr}, \mathrm{cm}^{-1}\right): \gamma$ $2950(\mathrm{C}-\mathrm{H}), 1738(>\mathrm{C}=\mathrm{O}), 1615(\mathrm{C}=\mathrm{N}) \mathrm{cm}^{-1} ;{ }^{1} \mathrm{H}$ NMR $\left(\mathrm{CDCl}_{3}\right): \delta 2.26\left(\mathrm{~s}, 3 \mathrm{H},-\mathrm{COCH}_{3}\right), 2.89$ 
(s, 3H, - $\mathrm{CH}_{3}$ ), 4.66 (s, 1H, -CH-), 7.30-7.74 (m, 9H, Ar-H); ${ }^{13} \mathrm{C}$ NMR (DMSO-d6): $\delta 21.4$ (C10), 27.0 (C-12), 64.4 (C-5), 134.4 (C-22), 126.8 (C-20 and C-24), 128.4 (C-21 and C-23), 129.2 (C-15 and C-17), 129.4 (C-14 and C-18), 130.6 (C-13), 131.6 (C-16), 132.0 (C-6), 142.4 (C-19), 144.0 (C-2), 152.2 (C-7), 160.6 (C-9), 196.8 (C-11); MS for $\mathrm{C}_{20} \mathrm{H}_{16} \mathrm{ClN}_{3} \mathrm{OS}: 381.10$ $\left(\mathrm{MH}^{+}, 100 \%\right), 383.12\left(\mathrm{MH}^{+1}, 383.2 \%\right), 382.08\left(\mathrm{MH}^{+2}, 24.4 \%\right)$; Elemental analysis: Calculated: C, 62.90; H, 4.24; Cl, 9.28; N, 11.00; Found: C, 62.88; H, 4.20; Cl, 9.26; N, 10.80

2.5. 1-(2-(4-methoxyphenyl)-7-methyl-5-phenyl-5H-[1,3,4]thiadiazolo[3,2- $\alpha]$ pyrimidine-6yl)ethanone $(4 d)$.

Obtained from 5-(4-methoxyphenyl)-1,3,4-thiadiazole-2-amine (1b, 2.07g, 10.00mmol), acetylacetone $(2.00 \mathrm{~g}, 20.00 \mathrm{mmol})$ benzaldehyde $(3 \mathrm{a}, 1.06 \mathrm{~g}, 10.00 \mathrm{mmol})$ and PTSA $(2.50 \mathrm{~g}$, $15.00 \mathrm{mmol}$ ) as yellow solid, yield $86 \%$ (3.24g), m.p. $144-146^{\circ} \mathrm{C}$. IR $\left(\mathrm{KBr}, \mathrm{cm}^{-1}\right): \gamma 2970(\mathrm{C}-$ $\mathrm{H}), 1744(>\mathrm{C}=\mathrm{O}), 1518(\mathrm{C}=\mathrm{N}) \mathrm{cm}^{-1} ;{ }^{1} \mathrm{H} \mathrm{NMR}\left(\mathrm{CDCl}_{3}\right): \delta 2.30\left(\mathrm{~s}, 3 \mathrm{H},-\mathrm{COCH}_{3}\right), 2.92(\mathrm{~s}, 3 \mathrm{H}$, $\left.-\mathrm{CH}_{3}\right), 3.84$ (s, 3H, - $\left.\mathrm{OCH}_{3}\right), 4.64$ (s, 1H, -CH-), 7.02-7.86 (m, 9H, Ar-H); ${ }^{13} \mathrm{C}$ NMR (DMSO$d 6): \delta 21.6(\mathrm{C}-10), 27.2(\mathrm{C}-12), 56.4\left(-\mathrm{OCH}_{3}\right), 64.2(\mathrm{C}-5), 114.6(\mathrm{C}-15$ and $\mathrm{C}-17), 123.2(\mathrm{C}-$ 13), 126.8 (C-22), 127.2 (C-20 and C-24), 128.8 (C-21 and C-23), 130.4 (C-14 and C-18), 132.2 (C-6), 143.4 (C-19), 144.2 (C-2), 152.2 (C-7), 160.0 (C-9), 163.0 (C-16), 196.8 (C-11); MS for $\mathrm{C}_{21} \mathrm{H}_{19} \mathrm{~N}_{3} \mathrm{O}_{2} \mathrm{~S}$ : $377.46\left(\mathrm{MH}^{+}, 100 \%\right), 378.10\left(\mathrm{MH}^{+1}, 25 \%\right), 379.12\left(\mathrm{MH}^{+2}, 6.2 \%\right)$; Elemental analysis: Calculated: C, 66.80; H, 5.06; N, 11.12; Found: C, 66.78; H, 5.00; N, 11.10 .

2.6. 1-(2,5-bis(4-methoxyphenyl)-7-methyl-5H-[1,3,4]thiadiazolo[3,2- $\alpha]$ pyrimidine-6yl)ethanone (4e).

Obtained from 5-(4-methoxyphenyl)-1,3,4-thiadiazole-2-amine (1b, 2.07g, 10.00mmol), acetylacetone $(2.00 \mathrm{~g}, 20.00 \mathrm{mmol})$ 4-methoxybenzaldehyde $(3 \mathrm{~b}, 1.36 \mathrm{~g}, 10.00 \mathrm{mmol})$ and PTSA $(2.50 \mathrm{~g}, 15.00 \mathrm{mmol})$ as yellow solid, yield $80 \%(3.25 \mathrm{~g})$, m.p. $140-142^{\circ} \mathrm{C}$. IR $\left(\mathrm{KBr}, \mathrm{cm}^{-1}\right): \gamma$ $2955(\mathrm{C}-\mathrm{H}), 1728(>\mathrm{C}=\mathrm{O}), 1615(\mathrm{C}=\mathrm{N}) \mathrm{cm}^{-1} ;{ }^{1} \mathrm{H} \mathrm{NMR}\left(\mathrm{CDCl}_{3}\right): \delta 2.26\left(\mathrm{~s}, 3 \mathrm{H},-\mathrm{COCH}_{3}\right), 2.96$ $\left(\mathrm{s}, 3 \mathrm{H},-\mathrm{CH}_{3}\right), 3.84-3.88\left(\mathrm{~s}, 6 \mathrm{H},-\mathrm{OCH}_{3}\right), 4.60$ (s, $\left.1 \mathrm{H},-\mathrm{CH}-\right), 6.80-7.85(\mathrm{~m}, 8 \mathrm{H}, \mathrm{Ar}-\mathrm{H}) ;{ }^{13} \mathrm{C}$ NMR (DMSO-d6): $\delta 21.0(\mathrm{C}-10), 27.4(\mathrm{C}-12), 55.8\left(-\mathrm{OCH}_{3}\right), 56.4\left(-\mathrm{OCH}_{3}\right), 64.0(\mathrm{C}-5), 114.8$ (C-15 and C-17), 115.0 (C-21 and C-23), 123.0 (C-13), 126.2 (C-20 and C-24), 130.6 (C-14 and C-18), 132.4 (C-6), 136.0 (C-19), 144.4 (C-2), 152.2 (C-7), 158.8 (C-22), 160.6 (C-9), 163.2 (C-16), 196.2 (C-11); MS for $\mathrm{C}_{22} \mathrm{H}_{21} \mathrm{~N}_{3} \mathrm{O}_{3} \mathrm{~S}: 407.12\left(\mathrm{MH}^{+}, 100 \%\right), 408.10\left(\mathrm{MH}^{+1}, 26 \%\right)$, $409.08\left(\mathrm{MH}^{+2}, 5.8 \%\right)$; Elemental analysis: Calculated: $\mathrm{C}, 64.85 ; \mathrm{H}, 5.19$; N, 10.30; Found: C, $64.86 ; \mathrm{H}, 5.18 ; \mathrm{N}, 10.28$.

2.7. 1-(5-(4-chlorophenyl)-2-(4-methoxyphenyl)-7-methyl-5H-[1,3,4]thiadiazolo[3,2a]pyrimidine-6-yl)ethanone (4f).

Obtained from 5-(4-methoxyphenyl)-1,3,4-thiadiazole-2-amine $\quad(1 \mathrm{~b}, \quad 2.07 \mathrm{~g}$, $10.00 \mathrm{mmol})$, acetylacetone $(2.00 \mathrm{~g}, 20.00 \mathrm{mmol}) 4$-chlorobenzaldehyde $(3 \mathrm{c}, 1.40 \mathrm{~g}, 10.00 \mathrm{mmol})$ and PTSA $(2.50 \mathrm{~g}, 15.00 \mathrm{mmol})$ as yellow solid, yield $84 \%(3.45 \mathrm{~g})$, m.p. $150-152^{\circ} \mathrm{C}$. IR $(\mathrm{KBr}$, $\left.\mathrm{cm}^{-1}\right): \gamma 2960(\mathrm{C}-\mathrm{H}), 1740(>\mathrm{C}=\mathrm{O}), 1624(\mathrm{C}=\mathrm{N}) \mathrm{cm}^{-1} ;{ }^{1} \mathrm{H} \mathrm{NMR}\left(\mathrm{CDCl}_{3}\right): \delta 2.28(\mathrm{~s}, 3 \mathrm{H}$, $\left.\mathrm{COCH}_{3}\right), 2.90\left(\mathrm{~s}, 3 \mathrm{H},-\mathrm{CH}_{3}\right), 3.84\left(\mathrm{~s}, 6 \mathrm{H},-\mathrm{OCH}_{3}\right), 4.64$ (s, 1H, -CH-), 7.08-7.90 (m, 8H, Ar$\mathrm{H}) ;{ }^{13} \mathrm{C}$ NMR (DMSO- $\left.d 6\right): \delta 21.6(\mathrm{C}-10), 27.2(\mathrm{C}-12), 55.6\left(-\mathrm{OCH}_{3}\right), 64.8(\mathrm{C}-5), 114.6(\mathrm{C}-15$ and C-17), 124.0 (C-13), 126.4 (C-20 and C-24), 128.2 (C-21 and C-23) 130.4 (C-14 and C18), 132.2 (C-6) 132.4 (C-22), 141.2 (C-19), 144.6 (C-2), 152.2 (C-7), 160.6 (C-9), 163.0 (C16), 196.4 (C-11); MS for $\mathrm{C}_{21} \mathrm{H}_{18} \mathrm{ClN}_{3} \mathrm{O}_{2} \mathrm{~S}: 411.06\left(\mathrm{MH}^{+}, 100 \%\right), 413.08\left(\mathrm{MH}^{+1}, 37.2 \%\right)$, 
$412.08\left(\mathrm{MH}^{+2}, 25.4 \%\right)$; Elemental analysis: Calculated: C, 61.23; H, 4.40; Cl, 8.61; N, 10.20; Found: C, 61.22; H, 4.42; Cl, 8.62; N, 10.18 .

2.8. 1-(2-(4-chlorophenyl)-7-methyl-5-phenyl-5H-[1,3,4]thiadiazolo[3,2- $\alpha]$ pyrimidine-6yl)ethanone $(4 g)$.

Obtained from 5-(4-chlorophenyl)-1,3,4-thiadiazole-2-amine (1c, 2.11g, 10.00mmol), acetylacetone $(2.00 \mathrm{~g}, 20.00 \mathrm{mmol})$ benzaldehyde $(3 \mathrm{a}, 1.06 \mathrm{~g}, 10.00 \mathrm{mmol})$ and PTSA $(2.50 \mathrm{~g}$, $15.00 \mathrm{mmol})$ as yellow solid, yield $81 \%$ (3.08), m.p. 146-148 ${ }^{\circ} \mathrm{C}$. IR $\left(\mathrm{KBr}, \mathrm{cm}^{-1}\right): \gamma 2960(\mathrm{C}-\mathrm{H})$, $1726(>\mathrm{C}=\mathrm{O}), 1624(\mathrm{C}=\mathrm{N}) \mathrm{cm}^{-1} ;{ }^{1} \mathrm{H}$ NMR $\left(\mathrm{CDCl}_{3}\right): \delta 2.20\left(\mathrm{~s}, 3 \mathrm{H},-\mathrm{COCH}_{3}\right), 2.96(\mathrm{~s}, 3 \mathrm{H},-$ $\mathrm{CH}_{3}$ ), 4.68 (s, 1H, -CH-), 7.22-7.85 (m, 9H, Ar-H); ${ }^{13} \mathrm{C}$ NMR (DMSO-d6): $\delta 21.2$ (C-10), 27.4 (C-12), 64.6 (C-5), 126.4 (C-20 and C-24), 126.8 (C-22), 128.6 (C-21 and C-23), 128.8 (C-13), 129.0 (C-15 and C-17), 129.8 (C-14 and C-18), 132.2 (C-6), 138.2 (C-16), 143.6 (C-19), 143.8 (C-2), 150.8 (C-7), 158.8 (C-9), 196.2 (C-11); MS for $\mathrm{C}_{20} \mathrm{H}_{16} \mathrm{ClN}_{3} \mathrm{OS}: 381.07\left(\mathrm{MH}^{+}, 100 \%\right)$, $383.10\left(\mathrm{MH}^{+1}, 38.2\right), 382.08\left(\mathrm{MH}^{+2}, 24.0 \%\right), 384.08$ (10.0\%); Elemental analysis: Calculated: C, 62.92; H, 4.24; Cl, 9.28; N, 11.02; Found: C, 62.90; H, 4.22; Cl, 9.24; N, 11.00 .

2.9. 1-(2-(4-chlorophenyl)-5-(4-methoxyphenyl)-7-methyl-5H-[1,3,4]thiadiazolo[3,2a]pyrimidine-6-yl)ethanone (4h).

Obtained from 5-(4-chlorophenyl)-1,3,4-thiadiazole-2-amine (1c, 2.11g, 10.00mmol), acetylacetone $(2.00 \mathrm{~g}, 20.00 \mathrm{mmol})$ 4-methoxybenzaldehyde $(3 \mathrm{~b}, 1.36 \mathrm{~g}, 10.00 \mathrm{mmol})$ and PTSA $(2.50 \mathrm{~g}, 15.00 \mathrm{mmol})$ as yellow solid, yield $85 \%(3.49 \mathrm{~g})$, m.p. $156-158^{\circ} \mathrm{C} .{ }^{1} \mathrm{H} \mathrm{NMR}\left(\mathrm{CDCl}_{3}\right): \delta$ $2.30\left(\mathrm{~s}, 3 \mathrm{H},-\mathrm{COCH}_{3}\right), 2.98\left(\mathrm{~s}, 3 \mathrm{H},-\mathrm{CH}_{3}\right), 3.85\left(\mathrm{~s}, 3 \mathrm{H},-\mathrm{OCH}_{3}\right), 4.60$ (s, 1H, -CH-), 6.80-8.00 $(\mathrm{m}, 8 \mathrm{H}, \mathrm{Ar}-\mathrm{H}) ;{ }^{13} \mathrm{C}$ NMR (DMSO- $\left.d 6\right): \delta 21.6(\mathrm{C}-10), 27.2(\mathrm{C}-12), 56.2\left(-\mathrm{OCH}_{3}\right), 64.4(\mathrm{C}-5)$, 115.2 (C-21 and C-23), 125.8 (C-20 and C-24), 129.0 (C-13), 129.2 (C-15 and C-17), 129.8 (C-14 and C-18), 132.0 (C-6), 136.4 (C-19), 136.8 (C-16), 144.0 (C-2), 151.2 (C-7), 158.8 (C22), 160.6 (C-9), 196.8 (C-11); MS for $\mathrm{C}_{21} \mathrm{H}_{18} \mathrm{ClN}_{3} \mathrm{O}_{2} \mathrm{~S}: 411.08\left(\mathrm{MH}^{+}, 100 \%\right), 413.07\left(\mathrm{MH}^{+1}\right.$, $37.0 \%), 412.08\left(\mathrm{MH}^{+2}, 24.6 \%\right), 414.08$ (9.0\%); Elemental analysis: Calculated: $\mathrm{C}, 61.24 ; \mathrm{H}$, $4.40 ; \mathrm{Cl}, 8.61 ; \mathrm{N}, 10.20$; Found: C, 61.26; H, 4.38; Cl, 8.58; N, 10.16 .

2.10. 1-(2,5-bis(4-chlorophenyl)-7-methyl-5H-[1,3,4]thiadiazolo[3,2- $]$ pyrimidine-6yl)ethanone (4i).

Obtained from 5-(4-chlorophenyl)-1,3,4-thiadiazole-2-amine (1c, $2.11 \mathrm{~g}, 10.00 \mathrm{mmol})$, acetylacetone $(2.00 \mathrm{~g}, 20.00 \mathrm{mmol})$ 4-chlorobenzaldehyde $(3 \mathrm{c}, 1.40 \mathrm{~g}, 10.00 \mathrm{mmol})$ and PTSA $(2.50 \mathrm{~g}, 15.00 \mathrm{mmol})$ as yellow solid, yield $83 \%(3.44 \mathrm{~g})$, m.p. $164-166^{\circ} \mathrm{C}$. IR $\left(\mathrm{KBr}, \mathrm{cm}^{-1}\right): \gamma$ $2956(\mathrm{C}-\mathrm{H}), 1760(>\mathrm{C}=\mathrm{O}), 1628(\mathrm{C}=\mathrm{N}) \mathrm{cm}^{-1} ;{ }^{1} \mathrm{H} \mathrm{NMR}\left(\mathrm{CDCl}_{3}\right): \delta 2.32\left(\mathrm{~s}, 3 \mathrm{H},-\mathrm{COCH}_{3}\right), 2.96$ (s, 3H, - $\mathrm{CH}_{3}$ ), 4.66 (s, 1H, -CH-), 7.20-7.80 (m, 8H, Ar-H); ${ }^{13} \mathrm{C}$ NMR (DMSO-d6): $\delta 21.2(\mathrm{C}-$ 10), 27.0 (C-12), 64.2 (C-5), 126.4 (C-20 and C-24), 128.8 (C-21 and C-23), 129.0 (C-15 and C-17), 129.2 (C-13), 129.6 (C-14 and C-18), 132.4 (C-6), 132.8 (C-22), 137.2 (C-16), 142.0 (C-19), 143.8 (C-2), 151.8 (C-7), 160.4 (C-9), 196.4 (C-11); MS for $\mathrm{C}_{20} \mathrm{H}_{15} \mathrm{Cl}_{2} \mathrm{~N}_{3} \mathrm{OS}$ : 415.02 $\left(\mathrm{MH}^{+}, 100 \%\right), 417.03\left(\mathrm{MH}^{+1}, 68.8 \%\right), 416.02\left(\mathrm{MH}^{+2}, 24.6 \%\right), 418.02$ (16.4\%), 419 (11.0\%); Elemental analysis: Calculated: C, 57.70; H, 3.62; Cl, 17.03; N, 10.09; Found: C, 57.68; H, 3.64; $\mathrm{Cl}, 17.02 ; \mathrm{N}, 11.04$. 


\subsection{Biological assay.}

2.11.1. Antimicrobial activity

The synthesized compounds 1-(7-methyl-2,5-diphenyl-5H-[1,3,4]thiadiazolo(3,2a)pyrimidine-6-yl)ethanone (4a-i) were screened for in vitro antibacterial activity against Bacillus cereus (MTCC 8372), Staphylococcus aureus (MTCC 96) (gram-positive bacteria) Escherichia coli (MTCC 724) and Klebsiella pneumonia (gram-negative bacteria) using agar disc diffusion [29] method. The compounds (4a-i) were dissolved in DMF (dimethylformamide) at concentrations 50 and $100 \mu \mathrm{g} / \mathrm{mL}$ and placed on the inoculated plates. After allowing at $4^{\circ} \mathrm{C}$ for $2 \mathrm{~h}$, they were incubated at $37^{\circ} \mathrm{C}$ for $24 \mathrm{~h}$. Tetracycline was used as the standard drug, and the inhibition zone was measured in millimeters. Besides, in vitro antifungal screening [30] of the compounds (4a-i) was carried out against Aspergillus flavus (MTCC873), Aspergillus niger (MTCC 281), Fusarium oxysporum (MTCC 284), and Fusarium moniliform (MTCC 156) using Nystatin as standard drug. The microdilution method was used to evaluate the minimum inhibitory concentration (MIC) of all the synthesized compounds summarized in Table 1. The compounds were stable in the Nutrient agar and Potato dextrose agar. The MIC for fungal strains was performed using a 96-well plate. The fungi were maintained on potato dextrose agar (PDA) medium at $28^{\circ} \mathrm{C}$. Six replicate determinations were performed for all the compounds. Results were taken as a mean of at least three determinations.

\subsubsection{Antioxidant activity.}

The scavenging effect on nitric oxide was measured according to the method of Marcocci et al., [31] with a little modification [32]. Initially, $4 \mathrm{~mL}$ of a drug solution was added to $1 \mathrm{~mL}$ of sodium nitroprusside (SNP) solution $(25 \mathrm{mM})$ in a test tube and incubated at $29^{\circ} \mathrm{C}$ for $2 \mathrm{hr} .2 \mathrm{~mL}$ aliquot was diluted from the incubated solution with $1.2 \mathrm{~mL}$ Griess reagent (1\% sulphanilamide in $5 \% \mathrm{H}_{3} \mathrm{PO}_{4}$ and $0.1 \% \mathrm{~N}$-1-naphthyl ethylenediamine dihydrochloride). The absorbance of the chromophore that was formed during diazotization of the nitrite with sulphanilamide and subsequent coupling with $N$-1-naphthyl ethylenediamine dihydrochloride was immediately read at $550 \mathrm{~nm}$. The concentration was determined from a standard curve (y $=\mathrm{mx}+\mathrm{c})$ of sodium nitrite salt-treated in the same way with Griess reagent. Inhibition of nitrite formation by the drug or the standard plant antioxidant (Ascorbic acid) was calculated relative to the control.

$$
\text { Inhibition } \%=100\left(\mathrm{~A}_{\text {control }}-\mathrm{A}_{\text {test }}\right) / \mathrm{A}_{\text {control }}
$$

where, Atest is the absorbance of the control reaction mixture excluding the test compound/drug solution, and $\mathrm{A}_{\text {control }}$ is the absorbance of the test compounds/drug solution.

\section{Results and Discussion}

The synthesis of 1-(7-methyl-2,5-diphenyl-5H-[1,3,4]thiadiazolo(3,2- $\alpha$ )pyrimidine-6yl)ethanone (4a-i) in good yield was achieved by the cyclo-condensation reaction of active methylene acetylacetone (2) with substituted aromatic aldehydes (3a-c) and 2-amino-5-phenyl$[1,3,4]$ thiadiazole (1a-c) in the presence of PTSA [33] in acetonitrile as solvent (Scheme 1). The proposed mechanism for the above cyclo-condensation reaction is, as shown in Scheme 2. Initially, the in situ preparation of condensation intermediate (1) was achieved by the Knoevenagel condensation between active methylene compound acetylacetone with substituted aromatic aldehydes presence acidic PTSA. Meanwhile, the 2-amino-(1,3,4)- 
thiadiazole reacts with condensation intermediate (1) with the elimination of water molecule to yield the target product 1-(7-methyl-2,5-diphenyl-5H-[1,3,4]thiadiazolo(3,2- $\alpha$ )pyrimidine6-yl)ethanone (4a-i).

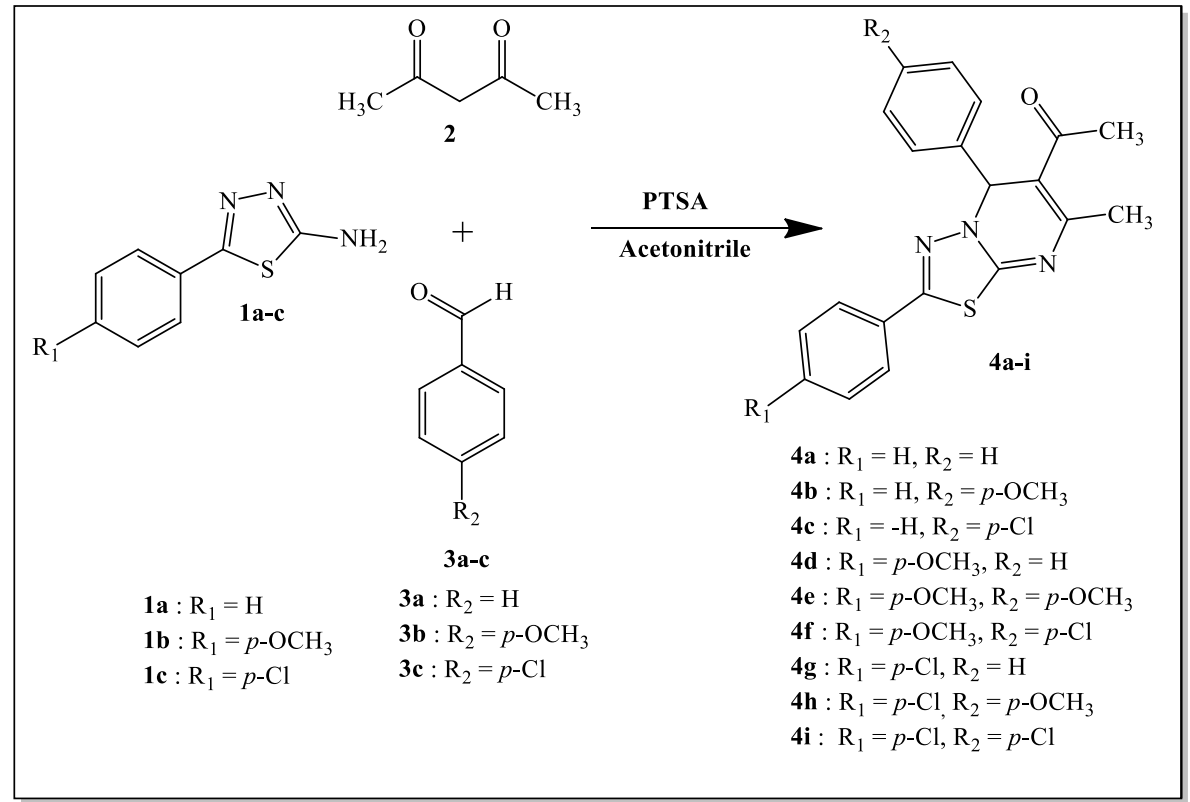

Scheme 1. Synthesis of bicyclic $[1,3,4]$ thiadiazole[3,2- $\alpha]$ pyrimidine analogs.

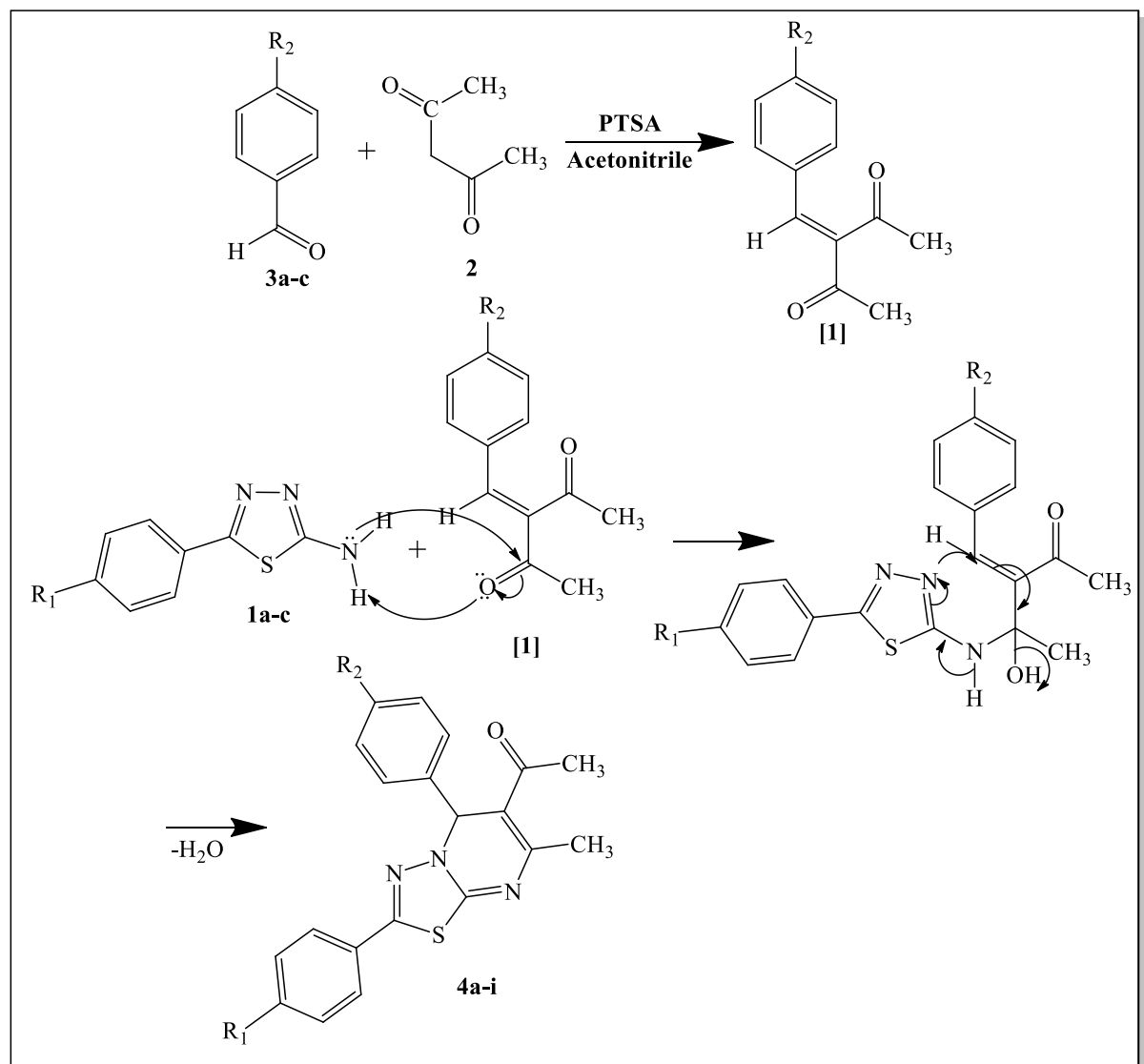

Scheme 2. Plausible mechanism for the formation of thiadiazolyl-pyrimidine analogs.

The newly synthesized compounds were characterized by IR, ${ }^{1} \mathrm{H}$ NMR, ${ }^{13} \mathrm{C}$ NMR, Mass, and elemental analysis. The IR spectra of (4a-i) showed the stretching vibration bands at around 2950-2972 $\mathrm{cm}^{-1}$ corresponding to the presence of $-\mathrm{CH}$ - group, vibration bands 1610$1628 \mathrm{~cm}^{-1}$ for $-\mathrm{C}=\mathrm{H}$ group and vibration band $1726-1760 \mathrm{~cm}^{-1}$ indicates the presence of $>\mathrm{C}=\mathrm{O}$ 
group in the compound. The ${ }^{1} \mathrm{H}$ NMR spectra of compounds (4a-i) showed the signals due to $\mathrm{CH}_{3}$ proton in the region $\delta 2.20$ to $2.32 \mathrm{ppm}$, singlet peaks of $-\mathrm{CO}-\mathrm{CH}_{3}$ group appeared in the region $\delta 2.89$ to $2.98 \mathrm{ppm}$, while singlet peak of $-\mathrm{CH}$ - group appeared in the region $\delta 4.60$ to $4.68 \mathrm{ppm}$ and all aromatic protons at $\delta 6.80$ to $8.00 \mathrm{ppm}$. The absence of $-\mathrm{NH}_{2}$ singlet peak in the region $\delta 8.40$ to $9.20 \mathrm{ppm}$ confirms the condensation product's formation. In ${ }^{13} \mathrm{C} \mathrm{NMR}$ spectra presence of additional peaks in the range of $\delta 21.0$ to $21.6 \mathrm{ppm}(\mathrm{C}-10), \delta 27.0$ to 27.4 ppm (C-12), and $\delta 64.0$ to 264.8 ppm (C-5) was observed. All synthesized compounds 4(a-i) showed $\mathrm{MH}^{+}$as a base peak in the mass spectra.

\subsection{Structure-activity relationship.}

\subsubsection{Antimicrobial assay.}

The series of synthesized compounds (4a-i) contains one of the nucleosides base pyrimidine moiety. We expected good antimicrobial activity, as shown in Table- 1 . The results revealed that the compounds $4 \mathrm{e}$ showed an excellent antibacterial effect against all the tested strains. This may be due to the presence of $-\mathrm{OCH}_{3}$ group on both para positions of the phenyl rings of thiadiazole as well as pyrimidine moieties. $4 \mathrm{~b}$ and $4 \mathrm{~h}$ were found to moderate, and $4 \mathrm{~d}$ and $4 \mathrm{f}$ showed less activity. It may be due to the presence of $-\mathrm{OCH}_{3}$ group on one of the phenyl rings of thiadiazole or pyrimidine ring. The compounds $4 \mathrm{c}$ and $4 \mathrm{i}$ were less active against bacterial strains, but they possess good antifungal activity. It may be the presence of $-\mathrm{Cl}$ group at the para position of the phenyl ring of pyrimidine, while $4 \mathrm{e}, 4 \mathrm{~g}$, and $4 \mathrm{~h}$ compounds showed moderate antifungal activity and the remaining compounds showed less antifungal activity.

\subsubsection{Antioxidant activity.}

The antioxidant activity of the bicyclic $[1,3,4]$ thiadiazolo[3,2- $\alpha]$ pyrimidine derivatives (4a-i) was evaluated in vitro by the nitric oxide radical scavenging assay. Most of the compounds tested significantly inhibited nitric oxide radical levels compared to that of the standard antioxidant ascorbic acid used in the study, as shown in Table-2. The compounds 4c, $4 \mathrm{e}, 4 \mathrm{f}$, and $4 \mathrm{i}$ exhibited a strong scavenging effect on the stable nitric oxide radical, with respective to $\mathrm{IC}_{50}$ values of $2.50 \pm 0.65,2.48 \pm 0.60,2.50 \pm 0.60$, and $2.50 \pm 0.67 \mu \mathrm{g} \mathrm{mL}-1$. These values are slightly lower than the positive control standard antioxidant ascorbic acid, indicating that compounds with chloro and methoxy group at the pyrimidine ring's para position and found to be the most potent antioxidant agents towards nitric oxide. The remaining compounds showed moderate activity.

\section{Conclusions}

In conclusion, we have synthesized the novel one-pot three-component chemical transformation of bicyclic [1,3,4]thiadiazolo[3,2- $\alpha]$ pyrimidine (4a-i) derivatives using electron-rich substituent on the phenyl ring of the aldehydes and acetylacetone. Here there is no need for using $\mathrm{V}_{2} \mathrm{O}_{5} / \mathrm{FAp}$ catalyst preparation. 


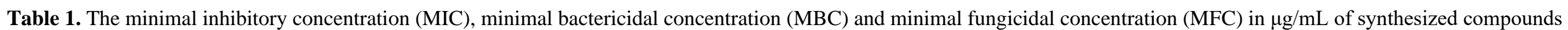

\begin{tabular}{|c|c|c|c|c|c|c|c|c|c|c|c|c|c|c|c|c|}
\hline \multirow{4}{*}{ Compounds } & \multicolumn{8}{|c|}{ Antibacterial activity } & \multirow{2}{*}{\multicolumn{8}{|c|}{ Antifungal activity }} \\
\hline & \multicolumn{4}{|c|}{ Gram positive } & \multicolumn{4}{|c|}{ Gram negative } & & & & & & & & \\
\hline & \multicolumn{2}{|c|}{ B. Cereus } & \multicolumn{2}{|c|}{ S. Aureus } & \multicolumn{2}{|c|}{ E. Coli } & \multicolumn{2}{|c|}{ K. Pneumonia } & \multicolumn{2}{|c|}{ A. Flavus } & \multicolumn{2}{|c|}{ A. Niger } & \multicolumn{2}{|c|}{ F. Oxysporum } & \multicolumn{2}{|c|}{ F. Monaliforme } \\
\hline & MIC & MBC & MIC & MBC & MIC & MBC & MIC & MBC & MIC & MFC & MIC & MFC & MIC & MFC & MIC & MFC \\
\hline $4 \mathbf{a}$ & 80 & 280 & 75 & 260 & 85 & 250 & 90 & 265 & 65 & 250 & 55 & 265 & 60 & 270 & 75 & 280 \\
\hline $4 \mathbf{b}$ & 15 & 130 & 20 & 140 & 20 & 145 & 15 & 135 & 60 & 290 & 65 & 285 & 50 & 280 & 60 & 275 \\
\hline $4 c$ & 60 & 250 & 45 & 255 & 55 & 260 & 50 & 240 & 20 & 135 & 10 & 120 & 20 & 125 & 15 & 120 \\
\hline 4d & 20 & 150 & 25 & 165 & 40 & 210 & 35 & 195 & 60 & 250 & 50 & 220 & 65 & 270 & 55 & 230 \\
\hline $4 e$ & 10 & 130 & 15 & 145 & 10 & 120 & 10 & 135 & 25 & 135 & 30 & 155 & 40 & 150 & 45 & 165 \\
\hline $4 f$ & 25 & 150 & 20 & 140 & 30 & 160 & 35 & 210 & 90 & 285 & 95 & 275 & 50 & 280 & 55 & 260 \\
\hline $4 g$ & 65 & 280 & 85 & 290 & 90 & 275 & 80 & 270 & 25 & 135 & 30 & 155 & 20 & 140 & 45 & 165 \\
\hline $4 h$ & 35 & 185 & 40 & 215 & 30 & 200 & 30 & 210 & 35 & 215 & 40 & 220 & 45 & 210 & 30 & 215 \\
\hline $4 \mathbf{i}$ & 60 & 240 & 75 & 260 & 55 & 250 & 50 & 250 & 10 & 120 & 15 & 125 & 20 & 130 & 15 & 130 \\
\hline Tetracycline & 5 & 120 & 10 & 120 & 12 & 120 & 8 & 120 & --- & --- & --- & --- & --- & --- & --- & --- \\
\hline Nystatin & --- & --- & --- & --- & --- & --- & --- & --- & 08 & 100 & 10 & 100 & 15 & 100 & 12 & 100 \\
\hline
\end{tabular}

Table 2. Antioxidant activity $\left(\mathrm{IC}_{50} / \mu \mathrm{g} \mathrm{mL} \mathrm{m}^{-1}\right.$ ) of the synthesized compounds (4a-i) against nitric oxide.

\begin{tabular}{|c|c|c|c|c|c|c|c|c|c|c|}
\hline Compounds & $4 a$ & $4 \mathrm{~b}$ & $4 c$ & $4 d$ & $4 e$ & $4 f$ & $4 \mathrm{~g}$ & $4 \mathrm{~h}$ & $4 i$ & $\begin{array}{l}\text { Ascorbic } \\
\text { acid }\end{array}$ \\
\hline Values & $2.50 \pm 0.40$ & $2.52 \pm 0.45$ & $2.50 \pm 0.65$ & $2.51 \pm 0.42$ & $2.48 \pm 0.60$ & $2.50 \pm 0.60$ & $2.55 \pm 0.40$ & $2.52 \pm 0.45$ & $2.50 \pm 0.67$ & $5.35 \pm 0.68$ \\
\hline
\end{tabular}


This method delivers a remarkable yield (80-86\%) of the target products 80-90 minutes with low-cost PTSA compared to the $\mathrm{V}_{2} \mathrm{O}_{5} / \mathrm{FAp}$ catalyst. All the synthesized compounds have been investigated for their in vitro antimicrobial and antioxidant activity.

Among the synthesized compounds, $4 \mathrm{e}$ showed an excellent antibacterial effect, $4 \mathrm{c}$ and $4 \mathrm{i}$ possess good antifungal activity, and $4 \mathrm{c}, 4 \mathrm{e}, 4 \mathrm{f}$, and $4 \mathrm{i}$ show excellent antioxidants in comparison with standard drugs. Hence, it could be a promising drug for microbial infections.

\section{Funding}

This research received no external funding.

\section{Acknowledgments}

The authors are grateful to Yuvaraja's College and Management, Vidyavardhaka College of Engineering, Mysuru, for providing the necessary facility to carry out the research work.

\section{Conflicts of Interest}

The authors declare no conflict of interest.

\section{References}

1. Neochoritis, C.G.; Zarganes-Tzitzikas, T.; Katsampoxaki-Hodgetts, K.; Dömling, A. Multicomponent Reactions: "Kinderleicht". J. Chem. Educ. 2020, 97, 3739-3745, https://doi.org/10.1021/acs.jchemed.0c00290.

2. Chen, X.-B.; Xiong, S.-L.; Xie, Z.-X.; Wang, Y.-C.; Liu, W. Three-Component One-Pot Synthesis of Highly Functionalized Bis-Indole Derivatives. ACS Omega 2019, 4, 11832-11837, https://doi.org/10.1021/acsomega.9b01159.

3. Shi, T.; Qin, F.; Li, Q.; Zhang, W. Copper-catalyzed three-component synthesis of pyrimidines from amidines and alcohols. Org. Biomol. Chem. 2018, 16, 9487-9491, https://doi.org/10.1039/C8OB02694G.

4. Muñoz-Torrero, D.; Lavilla, R.; Pérez-Areales, F.J.; Ghashghaei, O. Chapter Six - Multi-component reactions: A mighty journey partner for infectious tropical disease drug discovery. In Annu. Rep. Med. Chem., Chibale, K., Ed. Academic Press: 2019; Vol. 53, 181-217, https://doi.org/10.1016/bs.armc.2019.05.005.

5. Zhao, B.; Xu, Y.; Deng, Q.-G.; Liu, Z.; Wang, L.-Y.; Gao, Y. One-pot, three component synthesis of novel $5 \mathrm{H}-[1,3,4]$ thiadiazolo[3,2-a]pyrimidine-6-carboxylate derivatives by microwave irradiation. Tetrahedron Lett. 2014, 55, 4521-4524, https://doi.org/10.1016/j.tetlet.2014.06.073.

6. Sravanthi, B.; Kaviarasan, L.; Praveen, T.K.; Sai Kiran, P.S.S.; Pavankumar, C.; Gowramma, B. Synthesis and pharmacological evaluation of 1,3,4-thiadiazole bearing pyrimidine derivatives as STAT3 inhibitor for treatment of breast cancer. J Iran Chem Soc. 2020, 17, 2359-2370, https://doi.org/10.1007/s13738-02001932-z.

7. Yang, L.; Lin, S.; Xu, L.; Lin, J.; Zhao, C.; Huang, X. Novel activators and small-molecule inhibitors of STAT3 in cancer. Cytokine Growth Factor Rev. 2019, 49, 10-22, https://doi.org/10.1016/j.cytogfr.2019.10.005.

8. Kar, S.P.; Andrulis, I.L.; Brenner, H.; Burgess, S.; Chang-Claude, J.; Considine, D.; Dörk, T.; Evans, D.G.R.; Gago-Domínguez, M.; Giles, G.G.; Hartman, M.; Huo, D.; Kaaks, R.; Li, J.; Lophatananon, A.; Margolin, S.; Milne, R.L.; Muir, K.R.; Olsson, H.; Punie, K.; Radice, P.; Simard, J.; Tamimi, R.M.; Van Nieuwenhuysen, E.; Wendt, C.; Zheng, W.; Pharoah, P.D.P. The association between weight at birth and breast cancer risk revisited using Mendelian randomisation. Eur. J. Epidemiol. 2019, 34, 591-600, https://doi.org/10.1007/s10654-019-00485-7.

9. Nordin, N.; Yeap, S.K.; Rahman, H.S.; Zamberi, N.R.; Abu, N.; Mohamad, N.E.; How, C.W.; Masarudin, M.J.; Abdullah, R.; Alitheen, N.B. In vitro cytotoxicity and anti-cancer effects of citral nanostructured lipid carrier on MDA MBA-231 human breast cancer cells. Sci. Rep. 2019, 9, 1614, https://doi.org/10.1038/s41598-018-38214-X. 
10. Suiko, M.; Maekawa, K. Synthesis and Antitumor Activity of 2-Alkanesulfinyl (or Alkanesulfonyl)-7methyl-5H-1,3,4-thiadiazolo[3,2-a]pyrimidin-5-ones. Agric. Biol. Chem. 1977, 41, 2047-2053, https://doi.org/10.1080/00021369.1977.10862804.

11. El-Sayed, N.S.; El-Bendary, E.R.; El-Ashry, S.M.; El-Kerdawy, M.M. Synthesis and antitumor activity of new sulfonamide derivatives of thiadiazolo[3,2-a]pyrimidines. Eur. J. Med. Chem. 2011, 46, 3714-3720, https://doi.org/10.1016/j.ejmech.2011.05.037.

12. Rahman, D.E.A.; Mohamed, K.O. Synthesis of novel 1, 3, 4-thiadiazole analogues with expected anti-cancer activity. Der Pharma Chemica 2014, 6, 323-335.

13. Camerlingo, R.; Miceli, R.; Marra, L.; Rea, G.; D’Agnano, I.; Nardella, M.; Montella, R.; Morabito, A.; Normanno, N.; Tirino, V.; Rocco, G. Conditioned medium of primary lung cancer cells induces EMT in A549 lung cancer cell line by TGF-ß1 and miRNA21 cooperation. PLoS One 2019, 14, e0219597, https://doi.org/10.1371/journal.pone.0219597.

14. Vajrabhaya, L.-o.; Korsuwannawong, S. Cytotoxicity evaluation of a Thai herb using tetrazolium (MTT) and sulforhodamine B (SRB) assays. J Anal Sci Technol 2018, 9, 15, https://doi.org/10.1186/s40543-018-01460 .

15. Kerru, N.; Gummidi, L.; Maddila, S.N.; Bhaskaruni, S.V.H.S.; Maddila, S.; Jonnalagadda, S.B. Green synthesis and characterisation of novel [1,3,4]thiadiazolo/benzo[4,5]thiazolo[3,2-a]pyrimidines via multicomponent reaction using vanadium oxide loaded on fluorapatite as a robust and sustainable catalyst. RSC Advances 2020, 10, 19803-19810, https://doi.org/10.1039/D0RA02298E.

16. Dong, H.; Zhao, Y. Highly regioselective synthesis of 7-oxo-7H-[1,3,4]thiadiazolo[3,2-a]pyrimidine-5carboxylate derivatives under mild conditions. Tetrahedron Lett. 2019, 60, 1399-1403, https://doi.org/10.1016/j.tetlet.2019.04.005.

17. Mohamed, S.F.; Flefel, E.M.; Amr, A.E.-G.E.; Abd El-Shafy, D.N. Anti-HSV-1 activity and mechanism of action of some new synthesized substituted pyrimidine, thiopyrimidine and thiazolopyrimidine derivatives. Eur. J. Med. Chem. 2010, 45, 1494-1501, https://doi.org/10.1016/j.ejmech.2009.12.057.

18. Borthwick, A.D.; Davies, D.E.; Ertl, P.F.; Exall, A.M.; Haley, T.M.; Hart, G.J.; Jackson, D.L.; Parry, N.R.; Patikis, A.; Trivedi, N.; Weingarten, G.G.; Woolven, J.M. Design and Synthesis of Pyrrolidine-5,5'-transLactams (5-Oxo-hexahydropyrrolo[3,2-b]pyrroles) as Novel Mechanism-Based Inhibitors of Human Cytomegalovirus Protease. 4. Antiviral Activity and Plasma Stability. J. Med. Chem. 2003, 46, 4428-4449, https://doi.org/10.1021/jm030810w.

19. Flefel, E.E.; Salama, M.A.; El-Shahat, M.; El-Hashash, M.A.; El-Farargy, A.F. A Novel Synthesis of Some New Pyrimidine and Thiazolopyrimidine Derivatives for Anticancer Evaluation. Phosphorus, Sulfur, and Silicon and the Related Elements 2007, 182, 1739-1756, https://doi.org/10.1080/10426500701313912.

20. Pan, B.; Huang, R.; Zheng, L.; Chen, C.; Han, S.; Qu, D.; Zhu, M.; Wei, P. Thiazolidione derivatives as novel antibiofilm agents: Design, synthesis, biological evaluation, and structure-activity relationships. Eur. J. Med. Chem. 2011, 46, 819-824, https://doi.org/10.1016/j.ejmech.2010.12.014.

21. Gabr, M.T.; El-Gohary, N.S.; El-Bendary, E.R.; El-Kerdawy, M.M. Synthesis and in vitro antitumor activity of new series of benzothiazole and pyrimido[2,1-b]benzothiazole derivatives. Eur. J. Med. Chem. 2014, 85, 576-592, https://doi.org/10.1016/j.ejmech.2014.07.097.

22. Cai, D.; Zhang, Z.-H.; Chen, Y.; Yan, X.-J.; Zhang, S.-T.; Zou, L.-J.; Meng, L.-H.; Li, F.; Fu, B.-J. Synthesis of some new thiazolo[3,2-a]pyrimidine derivatives and screening of their in vitro antibacterial and antitubercular activities. Med. Chem. Res. 2016, 25, 292-302, https://doi.org/10.1007/s00044-015-1481-y.

23. Elizabeth, E.; Kaviarasan, L.; Praveen, T.K.; Kalirajan, R.; Manal, M.; Pulla, P.; Gowramma, B. 1,3,4Thiadiazolo (3,2-A) Pyrimidine-6-Carbonitrile Scaffold as PARP1 Inhibitors. Anti-cancer Agents Med. Chem. 2021, 21, 1-17, http://dx.doi.org/10.2174/1871520621666201216095018.

24. Matsuno, K; Masuda, Y; Uehara, Y; Sato, H; Muroya, A; Takahashi, O; Yokotagawa, T; Furuya, T; Okawara, T; Otsuka, M; Ogo, N. Identification of a new series of STAT3 inhibitors by virtual screening. ACS Med. Chem. Lett. 2010, 8, 371-375. https://doi.org/10.1021/ml1000273.

25. Rawat, S.; Singh, D.; Aman, S. Green Chemistry and Synthesis of Anticancer Molecules: A Review. Green Chem. 2019, 4.

26. Savateev, K.; Fedotov, V.; Butorin, I.; Eltsov, O.; Slepukhin, P.; Ulomsky, E.; Rusinov, V.; Litvinov, R.; Babkov, D.; Khokhlacheva, E.; Radaev, P.; Vassiliev, P.; Spasov, A. Nitrothiadiazolo[3,2-a]pyrimidines as promising antiglycating agents. Eur. J. Med. Chem. 2020, 185, 111808, https://doi.org/10.1016/j.ejmech.2019.111808. 
27. Khansole, G.S.; Angulwar, J.A.; Bhosale, V.N.; Choudhare, S.S. synthesis and antioxidant activity of pyrimido [4, 5-d][1, 3, 4] thiadiazolo [3, 2-a] pyrimidinedione. IJRAR-International Journal of Research and Analytical Reviews (IJRAR) 2019, 6, 525-530.

28. Young, G.; Eyre, W. III.-Oxidation of benzalthiosemicarbazone. Journal of the Chemical Society, Transactions 1901, 79, 54-60, https://doi.org/10.1039/CT9017900054.

29. Andrews, J.M.; for the, B.W.P.o.S.T. BSAC standardized disc susceptibility testing method (version 7). $J$. Antimicrob. Chemother. 2008, 62, 256-278, https://doi.org/10.1093/jac/dkn194.

30. Zgoda, J.R.; Porter, J.R. A Convenient Microdilution Method for Screening Natural Products Against Bacteria and Fungi. Pharm. Biol. 2001, 39, 221-225, https://doi.org/10.1076/phbi.39.3.221.5934.

31. Marcocci, L.; Maguire, J.J.; Droylefaix, M.T.; Packer, L. The Nitric Oxide-Scavenging Properties of Ginkgo Biloba Extract EGb 761. Biochem. Biophys. Res. Commun. 1994, 201, 748-755, https://doi.org/10.1006/bbrc.1994.1764.

32. Alisi, C.S.; Onyeze, G.O.C. Nitric oxide scavenging ability of ethyl acetate fraction of methanolic leaf extracts of Chromolaena odorata (Linn.). African Journal of Biochemistry Research 2008, 2, 145-150.

33. Jin, T.; Zhang, S.; Li, T. p-toluenesulfonic acid-catalyzed efficient synthesis of dihydropyrimidines: improved high yielding protocol for the biginelli reaction. Synth. Commun. 2002, 32, 1847-1851, https://doi.org/10.1081/SCC-120004068. 